\title{
The effect of Helicobacter pylori eradication on psoriasis
} course

\author{
Salih Levent Cinar ${ }^{1 *}$, Demet Kartal ${ }^{1}$, Gunes Gur ${ }^{2}$, Murat Borlu $^{3}$ and Nuran Alli ${ }^{2}$ \\ ${ }^{1}$ Assistant Professor of Dermatology, Erciyes University Faculty of Medicine, Dermatology and Venereology, 38039, Kayseri, Turkey \\ ${ }^{2}$ Professor of Dermatology, Ankara Numune Education and Research Hospital, Dermatology and Venereology, 06100, Ankara, Turkey \\ ${ }^{3}$ Professor of Dermatology, Erciyes University Faculty of Medicine, Dermatology and Venereology, 38039, Kayseri, Turkey
}

\begin{abstract}
Background: Psoriasis is a chronic disorder which develops in genetically vulnerable individuals with the effect of environmental factors. Some medications, trauma, stress and infections can trigger the disease. In this study we aimed to evaluate the possible effect of Helicobacter pylori eradication on psoriasis course.

Material and methods: 120 psoriasis patients who were seropositive for Helicobacter pylori were enrolled in the study. Eighty of the patients were given eradication therapy for H. pylori for fourteen days. Psoriasis area severity index (PASI) scores of the patients in both groups were calculated at the beginning, at the end of the eradication therapy $\left(15^{\text {th }}\right.$ day) and at $30^{\text {th }}$ day. The two groups were compared with respect to decrease in mean PASI scores.
\end{abstract}

Results: There was statistically significant decrease in the mean PASI score of the treatment group in percentages, both at $15^{\text {th }}$ and $30^{\text {th }}$ days. But there was no significant difference between the groups in terms of PASI-50 or PASI-75 response. There was no correlation between the body mass indexes of the patients and their response to eradication therapy.

Discussion and conclusion: Although there was decrease in the mean PASI scores after eradication therapy, the number of patients who had PASI-50 response was not significant. We claim that, H. pylori eradication is not effective in healing psoriasis.

\section{Introduction}

Psoriasis is a chronic, recurring, inflammatory skin disease which arises in genetically susceptible individuals due to environmental factors [1]. Vascular changes and T-cell mediated keratinocyte proliferation are the main characteristics in its pathogenesis [2].

Trauma, infections, hormonal changes, ultraviolet radiation, obesity and changes in the immune system can lead to the formation of psoriasis [3-5]. In the last few decades, Helicobacter pylori infection has been shown to cause some dermatological disorders, besides gastrointestinal system pathologies. Chronic urticaria, rosacea, alopecia areata and henoch schonlein purpura are believed to have a positive relation with Helicobacter pylori infection [6-8]. Besides these, there is potential relationship with psoriasis, lichen planus, dermatitis herpetiformis and Behcet's disease pathogenesis [9-11]. HP seroprevalence is almost $50 \%$ worldwide. But in Turkey this ratio has been reported to be $81 \%$ [12].

In this study we aimed to show the possible relationship between $\mathrm{H}$. pylori eradication and change in the psoriasis severity.

\section{Material and methods}

This study was conducted at Ankara Numune Education and Research Hospital Dermatology Department between January 2008 and December 2009. It was approved by the local ethics committee. Informed and written consents were taken from the volunteers.

Patients who were given the diagnosis of psoriasis histopathologically were enrolled in the study. The Helicobacter pylori positivity was established using the carbon-14 urea breath test. Patients who had psoriasis and who were positive for HP were included in the study. Patients younger than 18 years of age were excluded. Any individual who had used any systemic treatment in the last 6 months or who had used any topical treatment, other than emollients, in the last month were also excluded. Disease severity was evaluated by using the psoriasis area severity index (PASI). Any individual who had a PASI score bigger than 10, was not included in the study. After the confirmation of HP positivity, patients were given clarithromycin (500 $\mathrm{mg} /$ day BID), lansoprazole (30 mg/day BID) and amoxicillin (1000 $\mathrm{mg}$ /day BID) for 14 days for the eradication of HP. Patients' PASI scores were calculated before the eradication therapy, at the end of the eradication therapy ( $15^{\text {th }}$ day) and 15 days after eradication therapy $\left(30^{\text {th }}\right.$ day). Patients' body mass indexes (BMI) were also calculated, before the treatment, to find out any possible relation between the BMI and response to HP eradication.

\section{Statistical analyses}

To test for normality, the Shapiro-Wilk test was used, and variance homogeneity was confirmed using Levene's test. Values are expressed as means \pm standard deviation (for age and BMI) or medians (for PASI

Correspondence to: Salih Levent Cinar, Erciyes University Medical Faculty, Department of Skin and Venereal Diseases, 38039, Talas, Kayseri, Turkey, E-mail: sleventcinar@yahoo.com

Key words: Helicobacter pylori, psoriasis, psoriasis area severity index

Received: November 28, 2017; Accepted: December 26, 2017; Published: December 30, 2017 
and disease duration). Student's t-test and Mann Whitney U test were performed to evaluate differences between groups. Any $\mathrm{p}$ value less than 0.05 was accepted as significant. All calculations were made using PASW Statistics 16 software (SPSS, Chicago, Ill., USA).

\section{Results}

Eighty psoriasis patients [(44 male, 36 female), (mean age $38.3 \pm 13.4$ )], out of 123 , who were positive for HP and who fulfilled the inclusion criteria were enrolled in the study. These patients were given the mentioned drugs (clarithromycin, lansoprazole and amoxicillin) for HP eradication for 14 days. Forty psoriasis patients [( 21 male, 19 female), (mean age $34.3 \pm 11.9$ )] were chosen to be in the control group. The patients in the control group were not given any medication for HP eradication. The mean age and sex distribution between the patient and control groups were similar ( $\mathrm{p}=0.114$ and $\mathrm{p}=0.796$ respectively).

There was no statistically significant difference between the patient $(25.3 \pm 3.9)$ and control $(26.2 \pm 4.0)$ groups in terms of BMI values $(\mathrm{p}=0.257)$.

The mean disease duration was 11 years in the patient group and 9.8 years in the control group. Table 1 summarizes the demographic properties of the patients in both groups.

In the patients who used eradication therapy, there were statistically significant decreases in the mean PASI scores between pre-treatment and end of treatment $\left(15^{\text {th }}\right.$ day) and between pre-treatment and 15 days after treatment $\left(30^{\text {th }}\right.$ day). Table 2 summarizes the mean PASI scores before treatment, at $15^{\text {th }}$ day and at $30^{\text {th }}$ day.

The mean PASI scores of the control and drug groups were similar, before treatment $(\mathrm{p}=0,198)$. The changes in the mean PASI scores (by percentages) at days 15 and 30 were statistically significant in the drug group when compared with the control group $(\mathrm{p}<0,001)$. Six $(7,5$ $\%)$ patients in the drug group reached PASI-50 score which is the 50 percent decrease in the mean PASI score. None of the patients in the control group reached PASI-50 score. In terms of PASI-50 response there was no significant difference between the groups. No patients in the study reached PASI-75 response. Table 3 summarizes the number of patients who had PASI-50 response in both groups.

There was no correlation between the mean body mass indexes of the groups and patients' response to HP eradication $(\mathrm{p}=0,469)$.

\section{Discussion}

Psoriasis is a chronic, inflammatory skin disease with a prevalence of 1-6\% in different countries [13]. Males and females are found to be almost equally affected in most of the studies. In some rare studies, female predominance has been reported [14]. In our study male to female ratio was 1 , which was compatible with the previous studies.

Although psoriasis is one of the most common diseases of the dermatology practice, its etiopathogenesis is still not fully understood.

Table 1. Demographic properties of the patients in both groups.

\begin{tabular}{|c|c|c|c|}
\hline & Control group & Drug group & \multirow{2}{*}{} \\
\cline { 2 - 3 } & $(\mathrm{N}=40)$ & $(\mathrm{n}=120)$ & \\
\hline Age (years) & $34,3 \pm 11,9$ & $38,3 \pm 13,4$ & 0,114 \\
\hline Gender & & & \multirow{2}{*}{0,796} \\
\hline Male & $21(52,5 \%)$ & $44(55 \%)$ & \\
\hline Female & $19(47,5 \%)$ & $36(45 \%)$ & 0,257 \\
\hline Body mass index & $26,2 \pm 4,0$ & $25,3 \pm 3,9$ & 0,226 \\
\hline Disease duration & 9,8 & 11,0 & 0 \\
\hline
\end{tabular}

Table 2. Mean PASI scores before treatment, at $15^{\text {th }}$ day and at $30^{\text {th }}$ day. $(*$ beginning versus $15^{\text {th }}$ day; ${ }^{\mathbf{x}} 15^{\text {th }}$ day versus $30^{\text {th }}$ day).

\begin{tabular}{|c|c|c|c|}
\hline & Control group & Drug group & \multirow{2}{*}{$\boldsymbol{p}$} \\
\cline { 2 - 4 }$(\mathrm{n}=40)$ & $(\mathrm{n}=120)$ & 0.198 \\
\hline $\begin{array}{c}\text { Mean PASI before } \\
\text { treatment }\end{array}$ & 7,55 & 8,12 & $<0,001^{*}$ \\
\hline $\begin{array}{c}\text { Mean PASI at 15 } \\
\text { day }\end{array}$ & 7,05 & 5,90 & $<0,001^{\mathbf{x}}$ \\
\hline $\begin{array}{c}\text { Mean PASI at 30 } \\
\text { day }\end{array}$ & 6,90 & 5,00 & th \\
\hline
\end{tabular}

Table 3. Patients who reached PASI-50 score at 30th day.

\begin{tabular}{|c|c|c|c|}
\hline & Control group & Drug group & \multirow{2}{*}{$(\mathrm{p}$} \\
\cline { 2 - 4 } & $(\mathrm{n}=40)$ & $(\mathrm{n}=120)$ & 0 \\
\hline $\begin{array}{c}\text { Number of patients } \\
\text { who reached PASI- } \\
\text { 50 response }\end{array}$ & $0(0 \%)$ & $6(7,5 \%)$ & 0,550 \\
\hline
\end{tabular}

Chronic inflammation, in which the T-cells are the main actors, together with vascular changes and keratinocyte proliferation are the characteristics of the disease $[2,15]$. Recently, the roles of IL-12, IL-17 and IL-17 are presented [16,17]. Psoriasis is seen in genetically prone individuals after some environmental changes such as trauma, medications, emotional stress and infections [18]. Among the infections; upper respiratory tract infections due to streptococci are the most known ones [19]. Moreover, Candida albicans, Malassezia furfur, enterobacteriaceae and human papilloma virus infections have been shown to cause or deteriorate psoriasis [20-23]. Recently, HP infection is also thought to affect psoriasis clinic [24].

HP is a gram (-), microaerophilic bacteria with a sero-positivity up to $50-80 \%$ in different communities(24). It can cause numerous gastrointestinal pathologies [25]. The relationship between HP and dermatological diseases, was first stated by Crabtree et al. In this study the authors had investigated the effect of HP on dermatitis herpetiformis [9]. Latter studies indicated connection between HP infection and chronic urticaria, rosacea, alopecia areata, Sjogren's syndrome, Henoch-Schonlein purpura, lichen planus and Behcet's disease $[6-8,26,27]$. In some of these studies, clinical improvement had been reported after HP eradication. Personal abnormal or exaggerated response to bacterial polymorphism and environmental factors, is thought to cause different clinical pictures after HP infection [28].

Halasz et al. were the first to investigate the relationship between $\mathrm{HP}$ and psoriasis. In this study, antibodies to HP were found in a significant number of patients with psoriasis without known gastrointestinal complaints [29]. In another report, a psoriasis patient who was given HP eradication therapy for gastric pain had almost complete improvement in terms of psoriasis [30]. Likewise, clinical healing was reported in a patient with palmoplantar psoriasis, after HP eradication [31]. Qayoom et al. found out that HP prevalence was significantly higher in psoriasis patients with respect to control patients [32].

There are limited number of controlled studies, investigating the relationship between HP and psoriasis. Dauden et al. reported no difference between the control group and the HP eradicated group in terms of psoriasis severity. But the number of patients enrolled in this study was only 10 [33]. In our study 80 patients, in the drug group, were given HP eradication therapy and 40 patients were enrolled in the control group making a total number of 120 patients.

The mechanisms by which the HP eradication might improve the disease clinic are still contradictive. HP is thought to cause increased 
gastrointestinal permeability. Consequently, it leads to prolonged antigenic exposure. In addition to this, the structural antigens of HP can act as super antigens and take part in the etiopathogenesis of some diseases. The microvascular dysfunction, elevated fibrinogen levels and platelet activation which are caused by HP are also thought to be causative in some dermato-pathologies [24,34,35]. Eradication of HP can cause healing in some diseases by blocking one or more of the mechanisms emphasized above.

In our study, after HP eradication, there was statistically significant decrease in the mean PASI scores when expressed in percentages. But when the patients who reached PASI-50 scores were compared there was no significant difference between the treatment and control groups. We claim that the relationship between HP eradication and clinical improvement in psoriasis is suspicious, although there is significant decrease in the mean PASI score, by percentages.

The psoriasis prevalence was found to be higher in obese and overweight individuals. Obesity is thought to aggravate psoriasis due to the metabolic irregularities and changes in the cytokine profiles [36]. Naldi et al. postulated that BMI affected the early clinical response to systemic treatment for psoriasis [37]. In our study, we also tried to evaluate any possible relationship between the BMI of the patients and their response to the eradication therapy. But there was no significant relation.

As a result we claim that eradication of HP infection seems to be inefficacious in psoriasis patients, even though there was significant decrease in the mean PASI score in percentages. Because PASI-50, PASI-75 even recently PASI-90 scores are required to show success in psoriasis treatment. Decrease in the mean PASI scores in percentages gives rise to think that there can be a possible relation between HP infection and psoriasis etiopathogenesis. But the failure to achieve PASI-50 and PASI-75 scores makes us believe that eradication of HP has nothing to do for psoriasis treatment. WE believe that, further studies with larger number of patients are required to show the effect of HP eradication in psoriasis.

\section{Conflicts of interest}

The authors declare no conflicts of interest.

\section{Grant information} report.

The authors declare that no grants were involved in supporting this

\section{References}

1. Yan D, Afifi L, Jeon C, Cordoro KM, Liao W (2017) A cross-sectional study of psoriasis triggers among different ethno-racial groups. J Am Acad Dermatol 77: 756-758.e1.

2. Varricchi G, Granata F, Loffredo S, Genovese A, Marone G (2015) Angiogenesis and lymphangiogenesis in inflammatory skin disorders. J Am Acad Dermatol 73(1): 144-53.

3. Bartke U, Venten I, Kreuter A, Gubbay S, Altmeyer P, et al. (2004) Human immunodeficiency virus-associated psoriasis and psoriatic arthritis treated with infliximab. Br J Dermatol 150: 784-786.

4. Herron MD, Hinckley M, Hoffman MS, Papenfuss J, Hansen CB, et al. (2005) Impact of obesity and smoking on psoriasis presentation and management. Arch Dermatol 141: 1527-1534. [Crossref]

5. Steinz K, Schubert S, Harder J, Gerdes S, Mrowietz U, et al. (2014) Bacterial soft tissue infection in psoriasis despite induction of epidermal antimicrobial peptides. Exp Dermatol 23: 862-864.

6. Kutlubay Z, Zara T, Engin B, Serdaroglu S, Tüzün Y, et al. (2014) Helicobacter pylori infection and skin disorders. Hong Kong Med J 20: 317-24.
7. Magen E, Delgado JS (2014) Helicobacter pylori and skin autoimmune diseases. World J Gastroenterol 20: 1510-1516. [Crossref]

8. Saleh P, Naghavi BM, Herizchi H, Mokhtari F, Mirza AAA, et al. (2017) Effects of Helicobacter pylori treatment on rosacea: A single-arm clinical trial study. J Dermatol 44: 1033-1037.

9. Crabtree JE, O'Mahony S, Wyatt JI, Heatley RV, Vestey JP, et al. (1992) Helicobacter pylori serology in patients with coeliac disease and dermatitis herpetiformis. $J$ Clin Pathol 45: 597-600.

10. Kapsimali VD, Kanakis MA, Vaiopoulos GA, Kaklamanis PG (2010) Etiopathogenesis of Behçet's disease with emphasis on the role of immunological aberrations. Clin Rheumatol 29: 1211-1216.

11. Kazanowska M, DuA I, Radwan OM (2016) The presence of Helicobacter pylori in oral cavities of patients with leukoplakia and oral lichen planus. J Appl Oral Sci 24: 18-23. [Crossref]

12. Us D, Hasçelik G (1998) Seroprevalence of Helicobacter pylori infection in an Asymptomatic Turkish population. J Infect 37: 148-150.

13. Huerta C, Rivero E, Rodríguez LA (2007) Incidence and risk factors for psoriasis in the general population. Arch Dermatol 143: 1559-1565. [Crossref]

14. Kundakci N, Türsen U, Babiker MO, Gürgey E (2002) The evaluation of the sociodemographic and clinical features of Turkish psoriasis patients. Int J Dermatol 41: 220-224. [Crossref]

15. Prinz JC (2003) The role of T cells in psoriasis. J Eur Acad Dermatol Venereol 17 257-270. [Crossref]

16. Bissonnette R, Bourcier M, Gooderham M, Hong CH, Landells I, et al. (2017) Management of Moderate to Severe Plaque Psoriasis: The Emerging Role of IL-17 Inhibition. J Cutan Med Surg 21: 2S-40S. [Crossref]

17. Koutruba N, Emer J, Lebwohl M (2010) Review of ustekinumab, an interleukin-12 and interleukin-23 inhibitor used for the treatment of plaque psoriasis. Ther Clin Risk Manag 6: 123-141. [Crossref]

18. Krueger JG, Bowcock A (2005) Psoriasis pathophysiology: current concepts of pathogenesis. Ann Rheum Dis 64 Suppl 2: ii30-36. [Crossref]

19. Telfer NR, Chalmers RJ, Whale K, Colman G (1992) The role of streptococcal infection in the initiation of guttate psoriasis. Arch Dermatol 128: 39-42. [Crossref]

20. Fry L, Baker BS (2007) Triggering psoriasis: the role of infections and medications Clin Dermatol 25: 606-615. [Crossref]

21. Jain S, Gulhane S, Pandey N, Bisne E (2015) Human papilloma virus infection and psoriasis: Did human papilloma virus infection trigger psoriasis? Indian J Sex Transm Dis AIDS 36: 201-210.

22. Rudramurthy SM, Honnavar P, Chakrabarti A, Dogra S, Singh P, et al. (2014) Association of Malassezia species with psoriatic lesions. Mycoses 57: 483-488. [Crossref]

23. Waldman A, Gilhar A, Duek L, Berdicevsky I (2001) Incidence of Candida in psoriasis-a study on the fungal flora of psoriatic patients. Mycoses 44: 77-81. [Crossref]

24. Wedi B, Kapp A (2002) Helicobacter pylori infection in skin diseases: a critical appraisal. Am J Clin Dermatol 3: 273-282. [Crossref]

25. Alzahrani S, Lina TT, Gonzalez J, Pinchuk IV, Beswick EJ, et al. (2014) Effect of Helicobacter pylori on gastric epithelial cells. World J Gastroenterol 20: 127-167.

26. Hernando HAA, Booken N, Goerdt S, Singer MV, Harder H (2009) Helicobacter pylori infection and dermatologic diseases. Eur J Dermatol 19: 431-444.

27. Prelipcean CC, Mihai C, Gogalniceanu P, Mitrica D, Drug VL, et al. (2007) Extragastric manifestations of Helicobacter pylori infection. Rev Med Chir Soc Med Nat Iasi 111: $75-83$.

28. de Korwin JD, Ianiro G, Gibiino G, Gasbarrini A (2017) Helicobacter pylori infection and extragastric diseases in 2017. Helicobacter 22: e12411.

29. Halasz CL (1996) Helicobacter pylori antibodies in patients with psoriasis. Arch Dermatol 132: 95-96. [Crossref]

30. Ali M, Whitehead M (2008) Clearance of chronic psoriasis after eradication therapy for Helicobacter pylori infection. J Eur Acad Dermatol Venereol 22: 753-754.

31. Hübner AM, Tenbaum SP (2008) Complete remission of palmoplantar psoriasis through Helicobacter pylori eradication: a case report. Clin Exp Dermatol 33: 339-340. 
32. Qayoom S, Ahmad QM (2003) Psoriasis and Helicobacter pylori. Indian J Dermatol Venereol Leprol 69: 133-134. [Crossref]

33. Daudén E, Vázquez CMA, Peñas PF, Pajares JM, García DA (2000) Association of Helicobacter pylori infection with psoriasis and lichen planus: prevalence and effect of eradication therapy. Arch Dermatol 136: 1275-1276.

34. Warren JR (2000) Gastric pathology associated with Helicobacter pylori. Gastroenterol Clin North Am 29: 705-751. [Crossref]
35. Zito F, Di Castelnuovo A, D’Orazio A, Negrini R, De Lucia D, et al. (1999) Helicobacter pylori infection and the risk of myocardial infarction: role of fibrinogen and its genetic control. Thromb Haemost 82: 14-18.

36. Naldi L, Mercuri SR (2010) Epidemiology of comorbidities in psoriasis. Dermatol Ther 23: 114-118. [Crossref]

37. Naldi L, Addis A, Chimenti S, Giannetti A, Picardo M, et al. (2008) Impact of body mass index and obesity on clinical response to systemic treatment for psoriasis. Evidence from the Psocare project. Dermatology 217: 365-373. [Crossref]

Copyright: @2017 Cinar SL. This is an open-access article distributed under the terms of the Creative Commons Attribution License, which permits unrestricted use, distribution, and reproduction in any medium, provided the original author and source are credited. 